\title{
RESILIENSI EKONOMI MASYARAKAT DESA WISATA PENGLIPURAN DI TENGAH PANDEMI COVID-19
}

\author{
Ida Bagus Putra Negarayana \\ Program Studi Manajemen Kepariwisataan, Politeknik Pariwisata Bali \\ Jalan Darmawangsa, Kampial, Nusa Dua \\ negarayana@ppb.ac.id
}

\begin{tabular}{l|l|l} 
Received: August, 2021 & Accepted: August, 2021 & Published: September, 2021
\end{tabular}

\begin{abstract}
Penglipuran Tourism Village feels the bad impact of the Covid-19 pandemic on its tourism activities. Before the pandemic, the rapid tourism activity in Penglipuran Tourism Village made many rural communities dependent on the tourism sector. However, due to the prolonged pandemic, many people have to change professions to be able to survive and the economy cannot run properly. Therefore, this study aims to analyze the economic resilience of the local community of Penglipuran Tourism Village in the midst of the Covid-19 pandemic. This study uses quantitative and qualitative methods (Mix Method). From the research, it was found that the economic condition of the Penglipuran Tourism Village Community experienced a decline in the midst of the Covid-19 Pandemic, this was influenced by several things, namely the decline in tourism activities in the village due to restrictions on activities and government policies, livelihood sources that changed for the worse and a decrease in income and public spending. The Economic Resilience of the Penglipuran Tourism Village Community is carried out in tourism activities by implementing the CHSE health protocol, village promotion, and village planning through improvements and additions to facilities and infrastructure support livelihood resilience efforts are carried out by digitizing products with online promotions, as well as the existence of delivery services that benefit buyers, the role of the government in resilience is to provide direct cash assistance to the community.
\end{abstract}

Keywords: Tourism Village, Resilience, Pandemic Covid-19

\begin{abstract}
Abstrak
Desa Wisata Penglipuran sangat merasakan dampak buruk pandemi Covid-19 terhadap kegiatan pariwisatanya. Sebelum adanya pandemi, pesatnya kegiatan pariwisata di Desa Wisata Penglipuran membuat masyarakat desa banyak yang bergantung pada sektor pariwisata. Namun karena pandemi yang berkepanjangan menjadikan banyak masyarakat harus beralih profesi untuk dapat menyambung hidup dan perekonomian menjadi tidak dapat berjalan dengan baik. Oleh karena itu penelitian ini bertujuan untuk menganalisis resiliensi ekonomi masyarakat lokal Desa Wisata Penglipuran di tengah pandemi Covid-19. Penelitian ini menggunakan metode kuantitatif dan kualitatif (Mix Method). Dari penelitian didapatkan bahwa kondisi Perekonomian Masyarakat Desa Wisata Penglipuran mengalami penurunan di Tengah Pandemi Covid-19, hal ini dipengaruhi oleh beberapa hal yaitu
\end{abstract}


Negarayana

menurunnya kegiatan pariwisata yang ada di desa akibat pembatasan aktivitas dan kebijakan pemerintah, sumber mata pencaharian yang berubah semakin buruk dan penurunan pendapatan serta pengeluaran masyarakat. Resiliensi Ekonomi Masyarakat Desa Wisata Penglipuran dilakukan pada kegiatan pariwisata dengan penerapan protokol kesehatan CHSE, promosi desa, dan penataan desa melalui perbaikan serta penambahan fasilitas sarana dan prasarana penunjang. Upaya resiliensi sumber mata pencaharian dilakukan digitalisasi produk dengan promosi online, serta adanya jasa layanan pengiriman yang menguntungkan pembeli, peran pemerintah dalam resiliensi yaitu memberikan bantuan langsung tunai kepada masyarakat.

\section{Kata Kunci: Desa Wisata, Resiliensi, Pandemic Covid-19}

\section{PENDAHULUAN}

Kemunculan pandemi Covid-19 pada akhir tahun 2019 tidak hanya menjadi krisis kesehatan, namun juga krisis ekonomi secara global. Mekanisme penyebaran Covid-19 tidak hanya melalui kontak antara manusia dengan manusia, melainkan fasilitas publik termasuk moda transportasi juga diyakini berperan sebagai vektor penyebaran virus (Dietz et al., 2020). Kondisi ini menyebabkan berwisata dianggap menjadi salah satu katalisator penyebaran penyakit (Hall et al., 2020).

Bali sebagai salah satu destinasi pariwisata dunia yang mengandalkan sektor pariwisata sebagai sektor utama pendongkrak perekonomian masyarakat, harus menerima dampak buruk adanya wabah Covid-19. Bagi sebagian masyarakat, masa pandemi ini mungkin mulai terasa melelahkan. Banyak pihak melihat masa pandemi ini sebagai sebuah bentuk ketidakpastian. Meski banyak penelitian sedang dilakukan mengenai pandemi, hingga kini belum ada data resmi yang valid mengenai kapan masa pandemi akan berakhir. Dari sisi destinasi pariwisata, desa wisata yang sedang gencar dikembangkan oleh pemerintah baik pusat dan daerah juga harus melakukan adaptasi kenormalan baru (new normal) apabila tetap ingin menjaga eksistensi pada kondisi saat ini. Kemandirian desa wisata memang diuji dalam masa pandemi ini.

Desa wisata yang memiliki banyak pemasukan dari kegiatan wisata kini harus mengatur ulang strategi untuk tetap bertahan dengan kemandirian yang dibentuk. Desa Wisata Penglipuran sebagai salah satu daya tarik wisata yang ada di Bali, sangat merasakan dampak buruk pandemi Covid-19 terhadap kegiatan pariwisatanya. Desa Wisata Penglipuran dikenal sebagai desa terbersih di dunia, memiliki berbagai kekhasan tradisi dan budaya sebagai atraksi wisata utama. Sebelum adanya pandemi Covid-19 desa ini tidak pernah sepi oleh kunjungan wisatawan. Dikutip dari Tribunnews.com, berdasarkan hasil wawancara dengan Bapak Nengah Moneng, selaku Kepala Pengelola Desa Wisata Penglipuran, menyatakan bahwa, data terakhir kunjungan wisatawan ke Desa Wisata Penglipuran tercatat sebanyak 262.401 orang pada tahun 2019, yang terdiri dari 204.309 wisatawan domestik, 58.362 wisatawan mancanegara, (Mercury, 2019, Tribunnews.com).

Pesatnya kegiatan pariwisata di Desa Wisata Penglipuran membuat masyarakat desa banyak yang bergantung pada sektor pariwisata. Masyarakat Desa Wisata Penglipuran banyak berusaha pada sektor ekonomi kreatif. Seperti menjual lukisan, kain khas Bali, kerajinan tangan, makanan dan minuman khas desa. Dapat diamati setiap rumah yang ada di Desa Wisata Penglipuran menjual produk kerajinan, makanan dan minuman khas desa wisata. Kegiatan ekonomi kreatif Desa Wisata Penglipuran di dukung oleh potensi hutan bambu yang ada di desa. Sehingga masyarakat desa cukup banyak menjadi pengrajin anyaman bambu. Produk kerajinan dan usaha kreatif 
masyarakat tersebut ditawarkan dan dijual ke wisatawan yang berkunjung sebagai oleh-oleh khas atau souvenir. Sebelum pandemi pendapatan masyarakat cukup tinggi dari penjualan produk tersebut dan sangat membantu perekonomian masyarakat. Pendapatan desa melalui kontribusi penjualan tiket masuk wisatawan cukup membantu desa adat dalam melengkapi kegiatan upacara dan upakara. Sehingga masyarakat tidak perlu mengeluarkan uang untuk biaya upacara di Pura umum seperti; Pura Dalem dan Pura Desa.

Adanya kegiatan pariwisata sangat mensejahterakan perekonomian masyarakat Desa Wisata Penglipuran. Hal tersebut terbukti dari pembangunan fasilitas sarana dan prasarana yang ada di desa sudah sangat lengkap dan dalam kondisi yang baik. Masyarakat mendapat kesempatan kerja yang lebih banyak dan masyarakat mendapat keringanan kontribusi ke desa adat untuk upacara agama. Desa adat memiliki pendapatan dari kegiatan pariwisata. Desa menjadi lebih tertata, bangunan adat dan situs sejarah terjaga kelestarian serta kebersihannya

Namun akibat adanya pandemi Covid19 pariwisata Desa Wisata Penglipuran sangat terpuruk. Desa Wisata Penglipuran sempat ditutup selama delapan bulan, dari bulan Maret sampai bulan Oktober 2020. Berdasarkan hasil observasi, meski Desa Wisata Penglipuran sudah dibuka namun desa ini masih terlihat lenggang, wisatawan yang berkunjung masih dapat dihitung. Pandemi Covid-19 menyebabkan pendapatan masyarakat yang berprofesi di sektor pariwisata baik didalam maupun luar desa, seperti penjual souvenir serta pengrajin menurun drastis dan bahkan sempat tidak dapat berjualan sama sekali. Dampak buruk pandemi sangat dirasakan oleh seluruh masyarakat Desa Wisata Penglipuran secara umum.

Berdasarkan hasil wawancara dengan Bapak Agus selaku Kepala Lingkungan Desa Penglipuran menyatakan bahwa, masyarakat yang memperoleh pendapatan dengan menjual hasil kerajinan kepada wisatawan, kini harus mengalami kerugian. Sepinya kunjungan wisatawan ke Desa Wisata Penglipuran membuat masyarakat harus berjuang mempertahankan roda perekonomiannya. Di tengah pandemi masyarakat harus tetap berjuang bertahan hidup, meski sektor pariwisata untuk saat ini tidak bisa diandalkan. Hal inilah yang menyebabkan penelitian terkait Resiliensi Ekonomi Masyarakat Desa Wisata di Tengah Pandemi Covid19 penting untuk dilakukan di Desa Wisata Penglipuran. Agar masyarakat mendapatkan gambaran terkait upaya mempertahankan kegiatan perekonomian mereka meski di tengah pandemi Covid-19.

Penelitian ini bertujuan untuk mengidentifikasi kondisi ekonomi masyarakat desa wisata di masa pandemi Covid-19 serta merumuskan upaya-upaya dalam mempertahankan kestabilan ekonomi masyarakat desa wisata. Resiliensi merupakan kemampuan manusia dalam menghadapi, mengatasi, mendapatkan kekuatan dan bahkan mampu mencapai transformasi diri setelah mengalami sebuah adversity, karena berangkat dari adversity atau kesengsaraan individu akan menemukan jalan pemecah masalah yang telah dialami, (Grothberg, 1999). Menurut Dawley dkk (2010) terdapat dua pemikiran utama di dalam resiliensi ekonomi, yaitu tentang resistensi (resistance) dalam menghadapi gangguan dan tentang kemampuan untuk kembali (bouncing back) pasca mendapat tekanan.

Pariwisata merupakan sektor yang paling rentan terkena tantangan baik itu perubahan iklim, pergeseran demografi dan krisis ekonomi. Menurut Nelson et al. (2007) mengenai sistem ketahanan pariwisata bahwa selain menghadapi perubahan yang ada, pariwisata juga harus memiliki fleksibilitas. Desa wisata adalah suatu bentuk integrasi antara atraksi, akomodasi, dan fasilitas 
pendukung yang disajikan dalam suatu struktur kehidupan masyarakat yang menyatu dengan tata cara dan tradisi yang berlaku (Nuryanti, 1993). Menurut Koentjaraningrat (2002:144) Masyarakat dapat juga diartikan sebagai sekumpulan manusia yang saling berinteraksi. Menurut Rahardjo (1999:30) desa didefinisikan sebagai suatu lingkungan yang penduduknya memiliki hubungan yang akrab dan serba informal di antara sesama warganya.

Menurut Tahrus (2020:7) Pandemi merupakan salah satu level penyakit berdasarkan penyebarannya. Secara umum, ada tiga level penyakit yang

dikenal dalam dunia epidemiologi, yaitu endemi, epidemi, dan pandemi. Centre for Disease Control and Prevention (CDC) memberikan definisi masing-masing pada tiga level penyakit tersebut: endemi adalah kehadiran konstan suatu penyakit menular pada suatu populasi dalam cakupan wilayah tertentu, epidemi adalah pertambahan angka kasus penyakit, seringkali secara tiba-tiba, di atas batas normal yang diprediksi pada populasi di suatu area, sedangkan pandemi adalah epidemi yang sudah menyebar ke beberapa negara dan benua dengan jumlah penularan yang massif.

\section{HASIL DAN PEMBAHASAN}

\subsection{Gambaran Umum Desa Wisata Penglipuran}

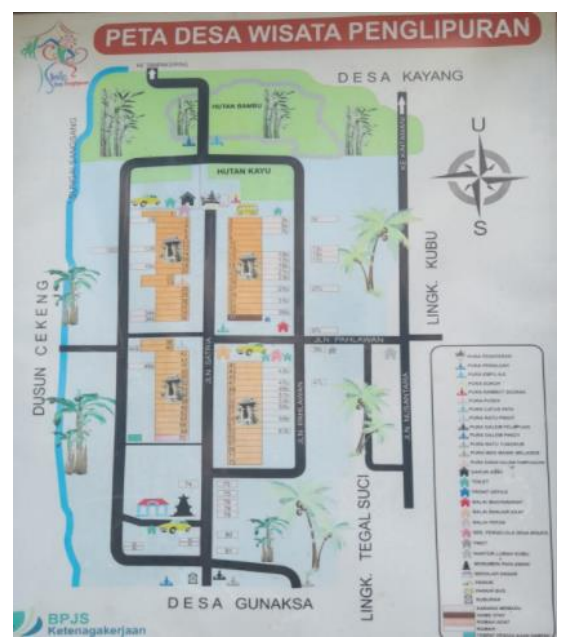

Gambar 1: Peta Desa Wisata Penglipuran

[Sumber: Dokumentasi Penelitian, 2021]

\section{METODE PENELITIAN}

Metode penelitian yang digunakan pada penelitian ini adalah kuantitatif dan kualitatif (mix method) dimana metode ini diambil dengan pertimbangan agar analisis dalam penelitian ini menjadi lebih komprehensif. Teknik pengumpulan data yang digunakan observasi partisipan, wawancara mendalam, survei, dan dokumentasi. Penentuan sampel dilakukan dengan rumus Slovin sehingga responden yang diambil yaitu 100 orang dan penentuan informan menggunakan Purposive Sampling. Variabel data dilihat dari faktor yang menyebabkan resiliensi ekonomi di Desa Wisata Penglipuran. Kemudian diamati ketahanan desa wisata dilihat dari tiga sisi yaitu; aspek pasar, kepemimpinan dan ikatan stakeholder lalu dianalisis mendalam terkait resiliensi ekonomi masyarakat sebagai pengusaha ekonomi kreatif dan yang berusaha pada sektor pariwisata. Teknik analisis data menggunakan uji validitas dan reliabilitas serta menggunakan interpretatif kualitatif dengan tahapan pengumpulan data dan reduksi data. 
Secara administratif Desa Wisata Penglipuran terletak di wilayah Kelurahan Kubu, Kecamatan Bangli, Kabupaten Bangli Provinsi Bali. Desa Wisata Penglipuran berada pada jarak 45 km dari Ibu Kota Provinsi Bali dan 5 km dari Ibu Kota Kabupaten Bangli. Desa ini dapat dicapai dengan menggunakan mobil atau sepeda motor dengan kondisi jalan yang cukup memadai. Berikut merupakan batas-batas wilayah Desa Wisata Penglipuran:

$\begin{array}{ll}\text { Utara } & \text { : Desa Kayang } \\ \text { Timur } & \text { : Desa Kubu } \\ \text { Selatan } & \text { : Desa Gunaksa } \\ \text { Barat } & \text { : Desa Cekeng }\end{array}$

Sejarah Desa Wisata Penglipuran berkaitan erat dengan keberadaan kerajaan Bangli yang dapat diketahui dari monografi Desa Wisata Penglipuran. Dimana konon disebutkan bahwa pada zaman Kerajaan Bangli, Raja Bangli memerlukan tenaga masyarakat dari Desa Bayung Gede, sebagai prajurit kerajaan. Karena letak Desa Bayung Gede cukup jauh dari pusat kerajaan Bangli, maka untuk memudahkan komunikasi dan mendekatkan jarak, beberapa warga Desa Bayung Gede dipindahkan dan dibuatkan tempat peristirahatan untuk prajurit di wilayah Desa Kubu yang berada sekitar empat kilometer di sebelah utara kota Bangli.

Keberadaan masyarakat Bayung yang tinggal di Desa Kubu inilah menjadi cikalbakal berdirinya Desa Wisata Penglipuran. Disamping itu disebutkan bahwa secara etimologi Penglipuran berasal dari kata Pengeling Pura. Pengeling (eling) yang artinya ingat/mengingat dan pura yang berarti tanah leluhur. Jadi kata Penglipuran berarti ingat akan tanah leluhur atau tempat asal mula mereka. Dinyatakan pula bahwa kata Penglipuran berasal dari kata penglipur lara yang artinya penghibur. Ini berarti bahwa Penglipuran merupakan tempat untuk menghibur orang yang datang.

\subsubsection{Kondisi Geografis Desa Wisata Penglipuran}

Secara geografi Desa Wisata Penglipuran terletak pada koordinat $08^{\circ} 08^{\circ} 30^{\circ}-08^{\circ} 31^{\circ} 07^{\circ}$ lintang selatan dan $115^{\circ} 13^{\circ} 43^{\circ}-115^{\circ} 27^{\circ} 24^{\circ}$ bujur timur dengan ketinggian 500-625 meter di atas permukaan laut. Desa Wisata Penglipuran termasuk beriklim sedang dengan suhu udara berkisar $18^{\circ} \mathrm{C}-32^{\circ} \mathrm{C}$ dengan curah hujan cukup tinggi berkisar 2000-2500 mm per tahun. Desa Wisata Penglipuran memiliki luas wilayah kurang lebih 112ha yang digunakan sebagai lahan pertanian, kawasan hutan, pemukiman, dan tempat suci. Luas wilayah tersebut didominasi oleh lahan pertanian yang memiliki luas 50 ha berupa lahan kering atau tegalan. Tata ruang Desa Wisata Penglipuran dikenal dengan Tri Mandala yakni utama mandala, madya mandala dan nista mandala. Utama Mandala merupakan areal atau kawasan yang diperuntukan sebagai tempat suci, terletak di bagian utara desa. Madya Mandala atau bagian tengah desa yang merupakan pemukiman warga masyarakat terdapat beberapa. Nista Mandala atau pada bagian selatan terdapat kuburan Desa Wisata Penglipuran dan juga beberapa tempat suci (Monografi Desa Penglipuran, 2013).

\subsubsection{Kondisi Demografis Desa Wisata Penglipuran}

Berdasarkan hasil wawancara dengan Bapak I Nengah Moneng selaku Ketua Pengelola Desa Wisata Penglipuran, bahwa hasil sensus penduduk terakhir menunjukkan jumlah penduduk desa kurang lebih 1.038 orang yang terdiri dari 240 kepala keluarga (KK). Jumlah penduduk Desa Wisata Penglipuran paling banyak adalah penduduk usia produktif yaitu berumur 15-56 tahun sejumlah (40\%). Ditinjau dari tingkat pendidikan, penduduk di Desa Wisata Penglipuran ada yang tidak tamat SD dan 
ada pula yang mencapai pendidikan S2 pendidikan masyarakat di Desa Wisata Penglipuran didominasi oleh tamatan SLTP yang berjumlah sekitar (50-60\%) kemudian yang melanjutkan ke jenjang perguruan tinggi baik Diploma atau S1 kurang lebih sekitar 150 orang. Serta terdapat pula penduduk yang memiliki tingkat pendidikan hingga jenjang S2 itu sekitar 5 orang.

Dilihat dari sistem mata pencaharian, penduduk Desa Wisata Penglipuran memiliki mata pencaharian yang beragam. Berdasarkan hasil wawancara terdapat 11 jenis sumber mata pencaharian penduduk Desa Wisata Penglipuran yang terdiri dari; petani, tni/polri, pns, guru, bidan, tukang, pengrajin bambu, pengolah makanan dan minuman kapal pesiar, peternak, penjahit, pelukis, pengrajin kayu.

\subsubsection{Komponen Produk Pariwisata Desa Wisata Penglipuran}

1) Attraction (Atraksi) desa Wisata Penglipuran memiliki beberapa atraksi wisata yang berkembang baik itu atraksi wisata budaya, alam dan juga buatan. Atraksi wisata budaya merupakan keunggulan Desa Wisata Penglipuran, terletak pada struktur fisik desa serupa dan seragam dari ujung utama desa sampai ke bagian hilir desa. Keunikannya karena di sepanjang jalan koridor desa hanya digunakan untuk pejalan kaki, yang kanan kirinya dilengkapi dengan atribut-atribut struktur desa seperti tembok penyengker, angkul-angkul (candi bentar khas), dan telajakan yang seragam. Keunikan budaya yang khas di Desa Wisata Penglipuran adalah tersedianya lahan khusus bagi orang yang berpoligami yang disebut karang memadu, lahan ini disediakan bagi penduduk desa yang beristri lebih dari satu, namun sampai sekarang lahan tersebut tidak pernah ada yang menempati, ini menunjukkan bahwa masyarakat Desa Wisata Penglipuran tidak pernah berpoligami. Atraksi wisata alam Desa Wisata Penglipuran yakni hutan bambu yang luasnya mencapai 45 hektare atau sekitar 40 persen dari luas keseluruhan Desa Wisata Penglipuran. Hutan bambu yang mengelilingi desa ini terus dijaga dan dilestarikan sampai saat ini sebagai bentuk pelestarian warisan dari para leluhur dan wujud nyata dalam menjaga keseimbangan antara manusia dan alam. Atraksi wisata buatan yang ditawarkan oleh Desa Penglipuran adalah sebuah festival budaya yang disebut Penglipuran Village Festival. Acara ini biasanya diselenggarakan di akhir tahun dengan rangkaian kegiatan yang beragam, mulai dari parade pakaian adat Bali, Barong Ngelawang, parade seni budaya, dan berbagai lomba lainnya.

2) Amenities (Fasilitas) fasilitas Pariwisata yang disediakan oleh Desa Wisata Penglipuran untuk memenuhi kebutuhan wisatawan selama berkunjung ke Desa sudah sangatlah lengkap. Desa Wisata Penglipuran telah memiliki homestay yang dikelola langsung oleh kelompok sadar wisata Desa Wisata Penglipuran. Fasilitas akomodasi ini juga sudah memiliki fasilitas lengkap berupa wifi, jasa laundry, parkir, dan toilet. Selain itu, fasilitas pariwisata yang juga sudah tersedia yaitu tersedia toilet umum, warung makan, parkir yang luas, wantilan/tempat istirahat, toko cinderamata, pengeras suara, tempat sampah, tempat cuci tangan, dan penyediaan protokol kesehatan (alat ukur suhu tubuh dan hand sanitizer yang tersebar di desa. 
3) Accessibility (Aksesibilitas) desa Wisata Penglipuran terletak di Kabupaten Bangli, untuk menuju ke desa ini memerlukan waktu 120 menit dari Bandara Ngurah rai dan kurang lebih 60 menit perjalanan dari Kota Denpasar. Terdapat banyak pilihan moda transportasi yang dapat digunakan oleh wisatawan yaitu taksi, transportasi online, kendaraan sewa, kendaraan pribadi, dan bus. Akses ke desa ini cukup bagus dan luas sehingga kendaraan besar masih bisa masuk ke lokasi. Selain itu, Desa ini memiliki 2 lokasi parkir yang cukup luas.

4) Ancillary (Pelayanan Tambahan) keberadaan Desa Wisata Penglipuran ditunjang dengan keberadaan lembaga yang mengelolanya. Dalam hal ini segala urusan yang terkait dengan pengelolaan pariwisata ditangani oleh Lembaga Pengelola Desa Wisata Penglipuran. Mereka yang dilibatkan sebagai pengurus Lembaga Pengelola Desa Wisata Penglipuran sepenuhnya merupakan warga desa adat setempat yang dianggap memiliki kompetensi yang terkait dengan bidang kepariwisataan. Lembaga desa adat memiliki kedudukan dan peran yang sangat penting dalam struktur organisasi Lembaga Pengelola Desa Wisata Penglipuran. Hal ini tercermin dari jabatan atau kedudukan dewan Pembina dipegang oleh prajuru desa adat sebagai representasi lembaga desa adat. Demikian pula kedudukan manager, wakil manager, koordinator administrasi, koordinator operasional, koordinator pengembangan, dan seksi- seksi sepenuhnya dipercayakan kepada warga desa adat setempat yang dianggap memiliki kompetensi pada bidangnya masing-masing. Lembaga tersebut akan menjadi bermanfaat bagi para wisatawan karena mereka akan dimudahkan dengan berbagai layanan seperti informasi, keamanan dan berbagai layanan lainnya.

\subsection{Pembahasan Kondisi Perekonomian Masyarakat Desa Wisata Penglipuran di Tengah Pandemi Covid-19}

Perekonomian masyarakat Desa Wisata Penglipuran yang didominasi dengan pertanian dan juga pengrajin khususnya kerajinan bambu dan didukung oleh perkembangan kegiatan pariwisata yang sangat pesat di Desa Wisata Penglipuran menyebabkan kondisi perekonomian desa secara umum juga mengalami penurunan selama pandemi covid-19 berlangsung. Dimana berpengaruh pada kegiatan pariwisata dan sumber mata pencaharian masyarakat Desa Wisata Penglipuran.

\subsubsection{Pengaruh Pandemi Covid-19 Terhadap Pariwisata Desa Wisata Penglipuran}

Desa Wisata Penglipuran merupakan salah satu daya tarik wisata yang menawarkan pengalaman kehidupan keseharian penduduk setempat. Keberadaan pariwisata di desa ini menjadikan sebagian besar masyarakat memiliki pekerjaan sampingan yang menunjang kegiatan pariwisata di desa seperti dengan berjualan souvenir, minuman khas (loloh cem-cem), jajanan khas (klepon) ataupun sebagai pengolah (pembuat) minuman khas (loloh cemcem), dan jajanan khas (klepon). 
Tabel 1: Bidang Pekerjaan Utama

\begin{tabular}{lllll}
\hline \multicolumn{1}{c}{ Valid } & Frequency & Percent & Valid Percent & $\begin{array}{c}\text { Cumulative } \\
\text { Percent }\end{array}$ \\
\hline Belum Bekerja & 3 & 3.0 & 3.0 & 3.0 \\
Pariwisata & 29 & 29.0 & 29.0 & 32.0 \\
Non Pariwisata & 65 & 65.0 & 65.0 & 100.0 \\
\hline Total & 100 & 100.0 & 100.0 & \\
\hline
\end{tabular}

Berdasarkan hal ini diketahui bahwa sebagian besar responden Desa Penglipuran bekerja dan pekerjaan utamanya di bidang Pariwisata. Pandemi Covid-19 tentu saja berpengaruh dalam perkembangan pariwisata di desa ini. Hal ini karena adanya kebijakan-kebijakan pembatasan yang diterapkan pemerintah sehingga kunjungan wisatawan ke desa juga menurun bahkan tidak ada kunjungan. Hal ini berdasarkan wawancara dengan Bapak I Nengah Moneng Beliau menuturkan bahwa:

"Pada masa awal Pandemi covid-19 itu Penglipuran sempat tutup pada Tanggal 18 Maret 2020 sampai 17 Oktober 2020, kami tutup dalam artian tidak menerima wisatawan. Kemudian pada tanggal 17 Oktober 2020- 31 Desember 2020 kami uji coba buka, uji coba ini dilakukan setelah kami diverifikasi dan diaudit mengenai protokol kesehatan itu ada dari provinsi, kemudian dari kementrian dalam hal ini sebagai desa wisata yang berkelanjutan, dan dalam hal ini CHSE nya. Per 1 Januari 2021, sampai saat ini kita buka, kunjungannya ya jelas menurun sebelum covid, kalau dulu kan kita bisa sampai 700 an perhari, kalau sekarang 150an perhari", (Wawancara, 27 Mei 2021).

Pengaruh pandemi covid-19 di bidang pariwisata juga berdampak kepada semua pelaku usaha yang mengandalkan kunjungan wisatawan juga tidak memiliki omset penjualan.

Tabel 2: Keterlibatan dalam usaha kerajinan, makanan, minuman Khas Desa Penglipuran

\begin{tabular}{lllll}
\hline Valid & Frequency & Percent & Valid Percent & $\begin{array}{l}\text { Cumulative } \\
\text { Percent }\end{array}$ \\
\hline Ya & 48 & 48.0 & 48.0 & 48.0 \\
Tidak & 52 & 52.0 & 52.0 & 100.0 \\
\hline Total & 100 & 100.0 & 100.0 & \\
\hline
\end{tabular}

Kegiatan produksi kerajinan, makanan dan minuman masih menjadi pekerjaan terbanyak di masyarakat saat ini, sehingga pendapatan dari kegiatan ini juga sangat menurun. Menurunnya omset penjualan dapat dilihat dari tabel 2 terkait permintaan kerajinan, makanan dan minuman yang menunjang kegiatan pariwisata.

Tabel 3: Permintaan Pasar Terhadap Kerajinan dan Kuliner Selama Pandemi Covid-19

\begin{tabular}{lllll}
\hline Valid & Frequency & Percent & $\begin{array}{c}\text { Valid } \\
\text { Percent }\end{array}$ & $\begin{array}{c}\text { Cumulative } \\
\text { Percent }\end{array}$ \\
\hline Ya & 48 & 48.0 & 48.0 & 48.0 \\
Tidak & 52 & 52.0 & 52.0 & 100.0 \\
\hline Total & 100 & 100.0 & 100.0 & \\
\hline
\end{tabular}

Dari tabel menunjukkan bahwa secara keseluruhan pandemi Covid-19 mengakibatkan penurunan permintaan pasar terhadap produk kerajinan dan kuliner di Desa Wisata Penglipuran.

\subsubsection{Pengaruh Pandemi Covid-19 Terhadap Sumber Mata Pencaharian Masyarakat Desa Wisata Penglipuran}

Penduduk Desa Wisata Penglipuran memiliki mata pencaharian yang 
beragam dimana terdapat 11 jenis sumber mata pencaharian penduduk Desa Wisata Penglipuran yang terdiri dari; petani, tni/polri, pns, guru, bidan, tukang, pengrajin bambu, pengolah makanan dan minuman kapal pesiar, peternak, penjahit, pelukis, pengrajin kayu. Pengaruh pandemi covid-19 terhadap sumber mata pencaharian masyarakat Desa Wisata Penglipuran yaitu berdampak terhadap penurunan jumlah mata pencaharian masyarakat.

Tabel 4: Mata Pencaharian sebelum pandemi Covid-19

\begin{tabular}{|c|c|c|c|c|}
\hline Valid & Frequency & Percent & $\begin{array}{c}\text { Valid } \\
\text { Percent }\end{array}$ & $\begin{array}{c}\text { Cumulative } \\
\text { Percent }\end{array}$ \\
\hline Belum Bekerja & 2 & 2.0 & 2.0 & 2.0 \\
\hline Pariwisata & 1 & 1.0 & 1.0 & 3.0 \\
\hline Pedagang & 19 & 19.0 & 19.0 & 22.0 \\
\hline $\begin{array}{l}\text { Pegawai } \\
\text { Negeri/TNI/POLRI }\end{array}$ & 1 & 1.0 & 1.0 & 23.0 \\
\hline Pegawai Swasta & 28 & 28.0 & 28.0 & 51.0 \\
\hline Pengrajin & 26 & 26.0 & 26.0 & 77.0 \\
\hline Penjaga Homestay & 1 & 1.0 & 1.0 & 78.0 \\
\hline Petani & 18 & 18.0 & 18.0 & $96 . .0$ \\
\hline Wiraswasta & 4 & 4.0 & 4.0 & 100.0 \\
\hline Total & 100 & 100.0 & 100.0 & \\
\hline
\end{tabular}

Mata Pencaharian sebelum pandemi covid-17 yaitu sebagai pegawai swasta sebanyak 28\% di sektor pariwisata, pengrajin sebanyak 26\%, sebanyak 19\% merupakan pedagang, $18 \%$ adalah petani, 4\% seorang wiraswasta, 2\% belum bekerja, dan masing-masing 1\% sebagai PNS, pariwisata dan penjaga homestay. Adapun mata pencaharian saat pandemi pada tabel 5 yaitu:

Tabel 5: Pencaharian saat pandemi Covid-19

\begin{tabular}{lllll}
\hline \multicolumn{1}{c}{ Valid } & Frequency & Percent & $\begin{array}{r}\text { Valid } \\
\text { Percent }\end{array}$ & \multicolumn{1}{c}{$\begin{array}{c}\text { Cumulative } \\
\text { Percent }\end{array}$} \\
\hline Belum Bekerja & 4 & 4.0 & 4.0 & 4.0 \\
Berubah Lebih Baik & 57 & 57.0 & 57.0 & 61.0 \\
Tetap sama & 39 & 39.0 & 39.0 & 100.0 \\
\hline Total & 100 & 100.0 & 100.0 & \\
\hline
\end{tabular}

Mata Pencaharian saat pandemi covid-17 mengalami perubahan atau pengurangan jenis pekerjaan yang dahulu terdapat pekerjaan tambahan di sektor pariwisata saat ini mengalami penurunan pekerjaan di bidang pariwisata hal ini dapat dilihat dari tabel 5 yaitu mata pencaharian berubah lebih buruk sebesar 57\%, selanjutnya 39\% mengatakan mata pencahariannya tetap sama dan 4\% mengatakan belum bekerja. Hal ini juga dipertegas dengan pernyataan dari bapak I Nengah Moneng mengatakan bahwa:

"Penjual souvenir, penjual makanan, dan penjaga homestay itu kan sebagai kegiatan tambahan mereka, tapi meskipun disebut dengan tambahan itu omsetnya kan cukup besar. Mereka kembali ke kehidupan seperti sebelum ada wisatawan, kembali misalnya mereka berkebun, kemudian beternak, ada juga peluang kecil-kecilan ada yang membuat canang, jual bibit tanaman bunga, trus seperti loloh cemcem masih mereka memproduksi tapi omsetnya turun drastis karena semua dibatasi. (wawancara, 27 Mei 2021).

Dalam wawancara ini juga dipertegas dimana mata pencaharian masyarakat Desa Wisata Penglipuran dominan berubah lebih buruk, beberapa upaya adaptasi baru dari masyarakat dalam 
sumber mata pencaharian sehingga tetap melakukan hal produktif.

\subsubsection{Pengaruh Pandemi Covid-19 Terhadap Pendapatan dan Pengeluaran Masyarakat Desa Wisata Penglipuran}

Tabel 6 : Pendapatan Sebelum Pandemi Covid-19

\begin{tabular}{lllll}
\hline \multicolumn{1}{c}{ Valid } & Frequency & Percent & $\begin{array}{c}\text { Valid } \\
\text { Percent }\end{array}$ & $\begin{array}{c}\text { Cumulative } \\
\text { Percent }\end{array}$ \\
\hline <2 juta & 5 & 5.0 & 5.0 & 5.0 \\
>20 Juta & 1 & 1.0 & 1.0 & 6.0 \\
Belum & 3 & 3.0 & 3.0 & 9.0 \\
Berpengahasilan & & & & \\
2-5 Juta & 68 & 68.0 & 68.0 & 77.0 \\
6-10 Juta & 23 & 23.0 & 23.0 & 100.0 \\
\hline Total & 100 & 100.0 & 100.0 & \\
\hline
\end{tabular}

Sebagian besar masyarakat Desa Penglipuran sebelum pandemi covid-19 memiliki penghasilan menengah ke atas, dimana didominasi oleh penghasilan $\mathrm{Rp}$
Pendapatan dan pengeluaran setiap masyarakat di Desa Wisata Penglipuran tentunya akan berbeda-beda setiap individu. Pandemi covid-19 ini menjadikan kegiatan perekonomian desa mengalami penurunan.

Tabel 7: Pendapatan Saat Pandemi Covid-19

\begin{tabular}{lllll}
\hline \multicolumn{1}{c}{ Valid } & Frequency & \multicolumn{1}{c}{ Percent } & $\begin{array}{c}\text { Valid } \\
\text { Percent }\end{array}$ & $\begin{array}{c}\text { Cumulative } \\
\text { Percent }\end{array}$ \\
\hline$<2$ juta & 70 & 70.0 & 70.0 & 70.0 \\
Belum & 3 & 3.0 & 3.0 & 73.0 \\
$\begin{array}{l}\text { Berpengahasilan } \\
\text { 2-5 Juta }\end{array}$ & 27 & 27.0 & 27.0 & 100.0 \\
\hline Total & 100 & 100.0 & 100.0 & \\
\hline
\end{tabular}

Sebagian besar masyarakat Desa Penglipuran saat pandemi covid-19 mengalami penurunan penghasilan, dan memiliki penghasilan menengah kebawah. Pengaruh covid19 terhadap penghasilan sangat signifikan. Penurunan pendapatan ini disebabkan oleh keterbatasan masyarakat untuk melakukan pekerjaannya baik mata pencaharian pokok maupun sampingan. Selanjutnya jika dilihat dari pengeluaran yang seharusnya berbanding lurus
2-5 Juta dan Rp 6-10 Juta dalam sebulan. Namun dalam pandemi ini pendapatan tersebut menurun yang dibuktikan dengan tabel 7 berikut:

Tabel 8: Pengeluaran sebelum pandemi covid-19

\begin{tabular}{lllll}
\hline \multicolumn{1}{c}{ Valid } & Frequency & \multicolumn{1}{c}{ Percent } & $\begin{array}{r}\text { Valid } \\
\text { Percent }\end{array}$ & $\begin{array}{c}\text { Cumulative } \\
\text { Percent }\end{array}$ \\
\hline$<$ juta & 17 & 17.0 & 17.0 & \\
Belum & 2 & 2.0 & 2.0 & \\
Berpengahasilan & & & & \\
2-5 Juta & 80 & 80.0 & 80.0 & \\
6-10 Juta & 1 & 1.0 & 1.0 & \\
\hline Total & 100 & 100.0 & 100.0 & \\
\hline
\end{tabular}

dengan pendapatan, dimana kondisi saat ini adalah keterbatasan jumlah pendapatan yang seharusnya menurunkan tingkat pengeluaran masyarakat.

Masyarakat Desa Penglipuran sebelum pandemi covid19 memiliki pengeluaran yang rata-rata menengah. Pada saat pandemi untuk pengeluarannya semakin menurun dibandingkan sebelum adanya pandemi 
Tabel 9: Pengeluaran sesudah pandemi covid-19

\begin{tabular}{lllll}
\hline \multicolumn{1}{c}{ Valid } & Frequency & Percent & $\begin{array}{r}\text { Valid } \\
\text { Percent }\end{array}$ & $\begin{array}{c}\text { Cumulative } \\
\text { Percent }\end{array}$ \\
\hline$<2$ juta & 43 & 43.0 & 43.0 & 43.0 \\
$\begin{array}{l}\text { Belum } \\
\text { Berpengahasilan }\end{array}$ & 1 & 1.0 & 1.0 & 44.0 \\
2-5 Juta & 56 & 56.0 & 56.0 & 100.0 \\
\hline Total & 100 & 100.0 & 100.0 & \\
\hline
\end{tabular}

Hal ini dapat dilihat dari perbandingan pengeluaran sebelum dan sesudah pandemi, dimana terdapat pengeluaran 6-10 juta dan jumlah pengeluaran Rp. 2-5 juta masih dengan persentase $80 \%$ sebelum pandemi, sedangkan saat pandemi pengeluaran Rp. 2-5 juta menurun menjadi $56 \%$ dengan meningkatnya pengeluaran $<$ Rp. 2 juta sebanyak 43\%. Terdapat juga beberapa masyarakat yang belum berpenghasilan karena responden masih berstatus pelajar atau mahasiswa sehingga pengeluaran ditanggung oleh kepala keluarga dan terdapat penurunan satu responden yang belum berpenghasilan karena sesudah pandemi, responden sudah tamat dari menempuh Pendidikan.

\subsection{Pembahasan Resiliensi Ekonomi Masyarakat Desa Wisata Penglipuran di Tengah Pandemi Covid-19}

Resiliensi ekonomi masyarakat Desa Wisata Penglipuran adalah upaya masyarakat dalam bertahan dan cara membangkitkan sektor ekonomi masyarakat di tengah pandemi Covid-19. Dalam penelitian ini akan dijabarkan resiliensi ekonomi masyarakat Desa Wisata Penglipuran di tengah pandemi Covid-19 yang akan dilihat dari beberapa hal, diantaranya; resiliensi aktivitas pariwisata Desa Wisata Penglipuran, stabilitas ekonomi masyarakat dan peran pemerintah dalam resiliensi ekonomi masyarakat.

\subsubsection{Resiliensi Aktivitas Pariwisata Desa Wisata Penglipuran}

Bertahan di tengah pandemi Covid-19 bukan sesuatu yang mudah. Banyak hal yang harus tim pengelola desa wisata siapkan, berikut merupakan upaya resiliensi yang dilakukan oleh pengelola Desa Wisata Penglipuran.

1) Penerapan Protokol Kesehatan CHSE (Cleanliness, Health Safety, Environment) sebelum dilakukan pembukaan aktivitas pariwisata, terlebih dahulu dilakukan verifikasi mengenai protokol kesehatan dari pemerintah Provinsi dan juga Kementerian Pariwisata dan Ekonomi Kreatif, untuk bisa lolos ke tahap verifikasi banyak hal yang perlu dipersiapkan terkait penerapan protokol CHSE. Bahkan di awal, sebelum terbentuknya Satgas Covid19, dari pengelola desa wisata berinisiatif untuk melakukan penyemprotan disinfektan ke seluruh area desa wisata. Berdasarkan hasil wawancara yang dilakukan dengan Bapak I Nengah Moneng, pada saat dilakukan verifikasi oleh tim penilaian provinsi dan pusat, beberapa rumah warga juga diambil sebagai sampel. Sampel diambil secara acak diantaranya; tiga pembuat kuliner, enam penjual souvenir dan enam fasilitas homestay. akhirnya Desa Wisata Penglipuran lolos dengan nilai yang sangat baik. Sehingga pada bulan Oktober 2020 kegiatan pariwisata dapat dibuka di Desa Wisata Penglipuran.

2) Promosi Desa Wisata upaya promosi dengan menggunakan media digital. Berdasarkan hasil wawancara dengan Bapak Riko, selaku staf pengelola yang membidangi even, menyatakan bahwa Desa Wisata Penglipuran telah memiliki akun media sosial seperti; Instagram, Fans Page, dan Website. Akun ini dibuat dan dikelola oleh para 
muda-mudi desa, media tersebut dimanfaatkan untuk mempromosikan aktivitas pariwisata Desa Wisata Penglipuran.

3) Penataaan Desa Wisata penutupan desa wisata akibat dari adanya pandemi Covid-19 dimanfaatkan oleh pengelola untuk melakukan penataan, perbaikan dan pemugaran baik dari segi kegiatan desa wisata maupun fasilitas dan sarana prasarana penunjang. Berdasarkan hasil wawancara dengan Bapak I Nengah Moneng, bahwa beberapa fasilitas yang diperbaiki selama pandemi Covid-19 diantaranya; renovasi atap homestay, perbaikan bale bengong (rest area), dan penataan taman homestay. Selain perbaikan pengelola juga melakukan penambahan fasilitas baru berupa; pembuatan sekretariat baru, loket pembelian tiket masuk, tempat cuci tangan, dan pos Satgas Covid-19.

\subsubsection{Resiliensi Sumber Mata Pencaharian Masyarakat}

Pandemi Covid-19 sangat berdampak buruk terhadap perekonomian masyarakat Desa Wisata Penglipuran. Seperti pada penjelasan di sub bab sebelumnya banyak masyarakat kehilangan pekerjaan hingga penurunan pendapatan akibat pandemi Covid-19, terutama bagi masyarakat Desa Wisata Penglipuran yang mengandalkan sektor pariwisata sebagai sumber mata pencaharian utama. Beberapa usaha yang tumbuh di tengah pandemi Covid19 diantaranya; pedagang tanaman hias atau bibit bunga dan juga pengembangbiakan ikan koi. Masyarakat juga berusaha mempertahankan sumber mata pencaharian mereka dengan berbagai upaya dimana diantaranya: upaya promosi online, penjualan produ kerajinan dan kuliner secara online, antar jemput pengiriman produk kerajinan dan kuliner secara online,.

Tabel 10: Upaya Promosi Produk Kerajinan dan Kuliner Secara Online di Desa Wisata Penglipuran

\begin{tabular}{lllll}
\hline \multicolumn{1}{r}{ Valid } & Frequency & \multicolumn{1}{c}{ Percent } & \multicolumn{1}{c}{$\begin{array}{c}\text { Valid } \\
\text { Percent }\end{array}$} & $\begin{array}{c}\text { Cumulative } \\
\text { Percent }\end{array}$ \\
\hline Mungkin & 26 & 26.0 & 26.0 & 26.0 \\
Tidak & 9 & 9.0 & 9.0 & 35.0 \\
Ya & 65 & 65.0 & 65.0 & 100.0 \\
\hline Total & 100 & 100.0 & 100.0 & \\
\hline
\end{tabular}

Promosi Produk Kerajinan dan Kuliner Secara Online. Hal ini menunjukkan bahwa sebagian besar masyarakat yang merupakan pelaku UMKM dalam hal ini pengrajin, pedagang, pengolah produk kerajinan dan kuliner melakukan upaya promosi secara online. Namun masih juga ada yang belum melakukan upaya promosi secara online serta beberapa masyarakat yang bukan pelaku UMKM tidak mengetahui secara pasti apakah terdapat upaya promosi secara online atau tidak.

Penjualan produk kerajinan dan kuliner secara online

Tabel 11: Penjualan Produk Kerajinan dan Kuliner Secara Online di Desa Wisata Penglipuran

\begin{tabular}{lllll}
\hline Valid & Frequency & Percent & $\begin{array}{c}\text { Valid } \\
\text { Percent }\end{array}$ & $\begin{array}{c}\text { Cumulative } \\
\text { Percent }\end{array}$ \\
\hline Mungkin & 39 & 39.0 & 39.0 & 39.0 \\
Tidak & 35 & 35.0 & 35.0 & 74.0 \\
Ya & 26 & 26.0 & 26.0 & 100.0 \\
\hline Total & 100 & 100.0 & 100.0 & \\
\hline
\end{tabular}

Hal ini menunjukkan bahwa sebagian besar masyarakat yang merupakan pelaku UMKM dalam hal ini pengrajin, pedagang, pengolah produk kerajinan 
dan kuliner melakukan penjualan secara online. Namun masih juga ada yang belum melakukan transaksi jual beli melalui sistem online.

Layanan antar jemput pengiriman produk kerajinan dan kuliner

Tabel 12: Layanan Pengiriman Produk Kerajinan dan Kuliner Selama Pandemi Covid-19

\begin{tabular}{lllll}
\hline Valid & Frequency & Percent & $\begin{array}{c}\text { Valid } \\
\text { Percent }\end{array}$ & $\begin{array}{c}\text { Cumulative } \\
\text { Percent }\end{array}$ \\
\hline Mungkin & 32 & 32.0 & 32.0 & 32.0 \\
Tidak & 17 & 17.0 & 17.0 & 49.0 \\
Ya & 51 & 51.0 & 51.0 & 100.0 \\
\hline Total & 100 & 100.0 & 100.0 & \\
\hline
\end{tabular}

Hal ini menunjukkan bahwa sebagian besar masyarakat Desa Wisata Penglipuran tidak mengetahui secara pasti apakah terdapat jasa layanan antar jemput untuk para konsumen yang ingin melakukan transaksi jual beli kerajinan, makanan, minuman dan produk lainnya di Desa Wisata Penglipuran. Hal ini dikarenakan ada beberapa pengrajin dan pengolah makanan minuman yang menyediakan ada pula yang tidak menyediakan layanan antar jemput.

\subsubsection{Peran Pemerintah dalam Resiliensi Ekonomi Masyarakat Desa Wisata Penglipuran}

Pemerintah memiliki peran penting dalam resiliensi perekonomian masyarakat desa wisata, hal ini terbukti dari hasil survei yang dilakukan sebanyak $24 \%$ menyatakan bahwa masyarakat memenuhi kebutuhan hidup dengan bantuan dari pemerintah. Berdasarkan hasil wawancara dengan Bapak I Nengah Moneng Beliau menuturkan bahwa:

"Nah pada intinya pariwisata itu berdampak tapi untuk bertahan masih bisa. Yang kedua desa adat menyadari bahwa desa adat sudah banyak memiliki asset dari pariwisata, jadi masyarakat diberikan ini bantuan sembako setiap bulan, termasuk vitamin. Sumbangan itu diberikan sampai maret-oktober (selama penutupan) tapi belakangan itu ada lagi tambahan beberapa, selain itu desa adat kami juga memberikan kebijakankebijakan tertentu, misalnya ada warganya yang diharuskan melakukan isolasi mandiri desa akan memberikan bantuan juga", (Wawancara, 27 Mei 2021).

Berdasarkan hasil wawancara tersebut dapat diketahui bahwa bantuan desa dari desa adat memiliki peran penting dalam membantu masyarakat memenuhi kebutuhan hidup mereka selama pandemi berlangsung.

Selain pemerintah desa yang dalam hal ini adalah desa adat, peran pemerintah kabupaten, provinsi dan pusat juga sangat penting. Dimana pemerintah kabupaten mengeluarkan kebijakan baru terkait biaya retribusi atau tiket masuk ke Desa Wisata Penglipuran. Sebenarnya harga tiket per Januari 2020 sudah ada wacana untuk kenaikan harga tiket masuk namun desa adat tidak mau mengingat fasilitas yang belum meningkat walaupun menurut beberapa pengamat Penglipuran sebagai desa wisata fasilitasnya sudah cukup memadai dan sangat representative, tetapi masyarakat adat belum memberikan izin. Namun setelah diadakan beberapa kali pertemuan akhirnya Desa Adat menyetujui kenaikan harga tiket dengan catatan 60\% diberikan ke Desa Wisata Penglipuran dan $40 \%$ ke pemerintah daerah. Akhirnya per 1 Januari ini tahun 2021 harga tiket resmi dinaikan, sekarang untuk domestik dewasa Rp 25.000, anakanak Rp 15.000 , kemudian dewasa asing Rp 50.000 anak-anak asing Rp 30.000. Dengan adanya pembagian seperti demikian, memberikan desa adat untuk lebih banyak keuntungan untuk dikelola 
Negarayana

dan digunakan untuk mendukung kesejahteraan masyarakat.

\section{KESIMPULAN}

Berdasarkan uraian hasil penelitian dapat disimpulkan beberapa hal dalam penelitian ini mencakup:

1) Kondisi Perekonomian Masyarakat Desa Wisata Penglipuran mengalami penurunan di Tengah Pandemi Covid-19, hal ini dipengaruhi oleh beberapa hal yaitu menurunnya kegiatan pariwisata, dimana sebanyak $68 \%$ responden bekerja dibidang pariwisata. Selanjutnya dipengaruhi oleh sumber mata pencaharian yang berubah semakin buruk, dimana mata pencaharian sampingan yang di desa ini sangat besar omsetnya mengalami penurunan drastis. Dan yang terakhir dipengaruhi oleh penurunan pendapatan, meskipun pendapatan masyarakat menurun namun pengeluaran masyarakat ikut menurun. Hal ini menurunkan kemungkinan terjadi masalah ekonomi jika pengeluaran lebih besar dibandingkan pendapatan masyarakat.

2) Resiliensi Ekonomi Masyarakat Desa Wisata Penglipuran di Tengah Pandemi Covid-19 dilakukan pada kegiatan pariwisata dengan penerapan protokol kesehatan CHSE, promosi desa, dan penataan desa melalui perbaikan serta penambahan fasilitas sarana dan prasarana penunjang. Selanjutnya upaya resiliensi sumber mata pencaharian dilakukan digitalisasi produk dengan promosi online, serta adanya jasa layanan pengiriman yang menguntungkan pembeli. Yang terakhir peran pemerintah dalam resiliensi yaitu memberikan bantuan langsung tunai kepada masyarakat oleh desa adat serta adanya upaya peningkatan harga tiket masuk untuk memberikan desa adat keuntungan lebih banyak yang bisa dikelola dan digunakan untuk mendukung

masyarakat.

Berdasarkan uraian kesimpulan terdapat rekomendasi dalam penelitian ini mencakup:

1) Masyarakat lokal sebaiknya lebih meningkatkan ketaatan dalam menerapkan protokol kesehatan, demi mencegah penularan Covid-19. Sehingga dapat memberikan rasa aman dan nyaman pada wisatawan yang berkunjung ke Desa Wisata Penglipuran.

2) Masyarakat lokal yang berprofesi sebagai pedagang souvenir pengolah makanan dan minuman khas Desa Wisata Penglipuran, sebaiknya lebih meningkatkan kegiatan promosi maupun penjualan secara online dengan memanfaatkan sosial media yang ada. Sehingga produk kerajinan dan kuliner Desa Wisata Penglipuran tetap terjual dengan baik dan pendapatan masyarakat bisa bertambah.

3) Pemerintah Desa Adat sebaiknya membantu resiliensi perekonomian masyarakat lokal bekerjasama dengan pemerintah daerah, provinsi maupun swasta dalam membantu mempromosikan produk UMKM masyarakat lokal Desa Wisata Penglipuran. Menampilkan produk lokal Desa Wisata Penglipuran pada kegiatan pameran atau even baik lokal, nasional maupun internasional. Sehingga produk UMKM Desa Wisata Penglipuran semakin dikenal dan pasar semakin tertarik untuk membeli produk masyarakat.

4) Secara akademis, sebaiknya dilakukan penelitian lebih lanjut terkait Dampak Pandemi terhadap Kegiatan Pariwisata di Desa Wisata Penglipuran. Sehingga dapat diketahui sejauh mana dampak yang ditimbulkan dan kerugian apa saja yang diterima oleh desa dan masyarakat akibat adanya pandemi Covid-19. 


\section{PERNYATAAN PENGHARGAAN}

Penulis menyadari banyak pihak yang telah membantu dalam penyelesaian Laporan ini, maka dari itu pada kesempatan ini penulis menyampaikan terima kasih kepada yang terhormat: Bapak I Nengah Moneng, selaku Ketua Pengelola Desa Wisata Penglipuran beserta jajaran, Bapak Agus, selaku Kepala Lingkungan Desa Wisata Penglipuran beserta seluruh masyarakat Desa Wisata Penglipuran, yang telah memberikan izin dan kesempatan untuk mencari data, bersedia memberikan data serta informasi terkait topik penelitian yang diteliti baik secara langsung maupun tidak langsung.

\section{DAFTAR PUSTAKA}

Adger W.N. 2006. Vulnerability. Global Environmental Change Volume 16. No.3 Hal: 268-281

Briguglio, L, et al. 2008. "Economic Vulnerability and Resilience." UNUWIDER. Vol 55: Hal 1-20.

Bungin, Burham. 2007. Penelitian Kualitatif Komunikasi, Ekonomi, Kebijakan Publik dan Ilmu Sosial Lainnya. Jakarta: Prenada Media Group.

Cochrane, J. (2010) The Sphere of Tourism Resilience. Jurnal Tourism Recreation Research. 2010, Vol 35 No 2, 173-185

Creswell, J.W. (1998), Qualitative Inquiry and Research Design, Choosing Among Five Traditions. California: Sage Publication. Hal 65.

Damanik, J. (2009). Pariwisata Indonesia. Yogyakarta: Pustaka Pelajar.

Dawley, S., Pike, A. \& Tomaney, J. (2010). Resilience, Adaptation and Adaptability. Cambridge Journal of Regions, 3, 59-70. http://dx.doi.org/10.1093/cjres/rsq 001

Daymon, C. dan Holloway, I. (2008). Metode-metode Riset Kualitatif: dalam Public Relations dan Marketing Communications. Yogyakarta: Penerbit Bentang.
Dietz, Leslie et al. (2020). 2019 Novel Coronavirus (COVID-19) Pandemic: Built Environment Considerations To Reduce Transmission. https://www.condair.com/

Grotberg, E. H. (1999). Tapping Your Inner Strength : How to Find the Resilience to Deal with Anything. Oakland, CA : New Harbinger Publications, Inc

Hair, J. F., Anderson, R. E., Tatham, R. L., \& Black, W.C. (1998). Multivariate Data Analysis. London: Prentice-Hall International (UK) Limited.

Hair, J. F., Hult, G. T. M., Ringle, C. M., \& Sarstedt, M. (2014). A Primer On Partial Least Squares Structural Equation Modeling (PLS - SEM). London: SAGE Publication Ltd.

Hall, et.al., (2020). A tale of two pandemics: How will COVID-19 and global trends in physical inactivity and sedentary behavior affect one another.

https://pubmed.ncbi.nlm.nih.gov

Imron, M.B. (2015). Meretas jalan meningkatkan Pendapatan Asli Daerah (PAD) melalui Desa Wisata Penglipuran, Bali. Jurnal Bina Praja, 7 , 279-288. http://dx.doi.org/10.21787/JBP.07. 2015.279-288.

Koentjaraningrat, Pengantar Ilmu Antropologi, (Jakarta: Rineka Cipta, 2002) hlm. 144. 